\title{
Penggunaan Metode Berbeda pada Pembuatan Telur Asin Terhadap Rasa dan Aroma
}

The Use of Different Methods of Making Salted Egg Flavour and Taste

\author{
Irmawaty \\ Jurusan Ilmu Peternakan Fakultas Sains dan Teknologi \\ Universitas Islam Negeri Alauddin Makassar \\ Korespondensi Email: irmawatymajid@gmail.com
}

\begin{abstract}
ABSTRAK
Tujuan dari penelitian ini yaitu untuk mengetahui pengaruh metode pemeraman, metode pasta dan metode perendaman pada pembuatan telur asin terhadap Aroma dan Rasa. Penelitian ini menggunakan Rancangan Acak Lengkap (RAL) dengan 3 perlakukan dan 4 ulangan. Setiap ulangan terdiri dari 3 butir telur. Hasil penelitian menunjukkan bahwa metode perendaman berpengaruh nyata $(\mathrm{P}<0,05)$ terhadap aroma telur asin dibandingkan metode pasta dan pemeraman, sedangkan penggunaan metode berbeda untuk rasa tidak terdapat perbedaan yang nyata $(P<0,05)$.
\end{abstract}

Kata kunci: Aroma dan Rasa, Metode Pembuatan Telur Asin , Telur asin,

\begin{abstract}
The aims of this study is to know the influence of curing method, paste method and and soalling in the alted egg making againt the aroma and flafour. Design of experimen in used completely random design, that i 3 treatment and 4 replicates. The result showed that the method of soaking efec real $(\mathrm{P}<0,05)$ of salted egg fragrance than pasta, and curing menthods, while the use of different method to get a sense there is not a noticeable difference $(\mathrm{P}<0,05)$.
\end{abstract}

Keywords: Flavour and Taste, Methods of Making Salted Egg, Salted Egg,

\section{PENDAHULUAN}

Telur merupakan hail ternak yang mempunyai andil besar dalam mengatasi masalah gizi yang terjadi di mayarakat. Hal ini dimungkinkan karena telur sarat akan zat gizi yang diperlukan untuk kehidupan yang sehat. Zat gizi yang ada pada telur sangat mudah dicerna dan dimanfaatkan oleh tubuh (Astawan, 2003). Telur mengandung hampir semua zat makanan hampir semua zat makanan yang diperlukan oleh tubuh, rasanya enak, mudah dicerna, menimbulkan rasa egar dan kuat di dalam tubuh dan di olah menjadi bermacam-macam masakan. Hampir emua orang menyukai telur ebagai bahan makanan (Sarwono, 1994). 
Telur mengandung protein lebih dari 10\% dan bahkan sebutir telur ayam mengandung protein $12,8 \%$ dan bebek $13,1 \%$. Di dalam telur juga terdapat aneka vitamin seperti vitamin $\mathrm{A}, \mathrm{D}, \mathrm{E}$ dan $\mathrm{K}$. Di samping itu, telur juga mengandung sejumlah mineral seperti zat besi, fosfor, kalsium, sodium, magnesium dalam jumlah yang cukup (Haryoto, 1994). Seperti produk peternakan lainnya, telur memiliki sifat mudah rusak, baik kerusakan alami, kimiawi maupun kerusakan akibat serangan mikroorganisme melalui pori-pori telur. Karena sifatnya yang mudah rusak tersebut, maka perlu adanya upaya mengawetkan telur untuk mempertahankan kualitas sekaligus meningkatkan nilai ekonominya.

Teknologi pengolahan telur asin merupakan usaha untuk mengawetkan, memperpanjang daya simpan, dan mencegah penurunan kualitas telur. Salah satu cara pengawetan yang bisa diterapkan adalah dengan penggaraman (pengasinan). Proses penggaraman atau pengasinan telur dapat dilakukan dengan beberapa metode.

Teknik pembuatan telur asin ada 3 metode: Pertama perendaman dalam larutan garam dapur yang jenuh, Kedua pemolesan telur dengan adonan batu bata atau abu dapur dan tanah liat yang padat atau kering, ketiga pembenaman telur dalam pasta batah merah atau abu dapur yang kental setengah basah. Ali (1992). Setiap metode pengasinan memiliki keistimewaan masing-masing. Pada proses penggaraman (pengasinan) dengan metode pemeraman dan pasta penetrasi garam lebing lambat dan albumin telur lebih padat. Jumlah garam yang bisa terserap ke dalam telur yaitu berkisar (5\%-10\%). Sebaliknya, metode penggaraman (pengasinan) dengan perendaman ini dilakukan dengan merendam telur asin ke dalam larutan garam jenuh. Metode ini memilki kemampuan penetrasi garam ke dalam telur berlangsung lebih cepat akan tetapi albumin telur relatif lebih basah (Lukman, 2008). Berdasarkan uraian tesebut, maka perlu dilakukan penelitian tentang bagaimana pengaruh metode yang berbeda dalam pembuatan telur asin terhadap aroma dan rasa.

Tujuan peneliatan ini untuk mengetahui pengaruh metode perendaman, pasta dan Perendaman pada pembuatan telur asin terhadap aroma dan rasa. Hasil penelitian ini diharapkan dapat memberikan informasi ilmiah yang bermanfaat bagi pengembangan ilmu pengetahuan dan teknologi pengendalian mutu dan keamanan pangan dibidang peternakan khususnya pengaruh metode perendaman, pasta dan pemeraman dalam pembuatan telur asin terhadap rasa dan aroma 


\section{METODE}

Penelitian ini dilaksanakan pada Bulan April 2017, di Laboratorium Teknologi Hasil Ternak Terpadu, Fakultas Sains dan Teknologi, Universitas Islam Negeri Alauddin Makassar.

\section{Alat dan Bahan}

Alat yang digunakan dalam penelitian ini antara lain: ayakan, baskom, toples, gelas kimia, ember, timba, panci, tupper ware, timbangan dan talang. Sedangkan Bahan yang digunakan pada penelitian ini yaitu telur itik umur kurang dari 7 hari sebanyak 60 butir, air, garam, abu gosok, dan batu bata, amplas, label dan kantong plastik.

\section{Jenis Penelitian}

Jenis penelitian ini adalah penelitian kuantitatif dengan metode experiment yaitu metode yang digunakan untuk mencari pengaruh perlakuan tertentu terhadap yang lain dalam kondisi yang terkendali.

\section{Rancangan percobaan}

Penelitian ini menggunakan rancanan acak lengkap (RAL) dengan 3 perlakukan dan 4 ulangan. Setiap ulangan terdiri dari 3 butir telur. Adapun perlakuannya adalah sebagai berikut: P1(Metode Pemeraman), P2 (Metode Pasta), dan P3 (Metode Perendaman).

\section{Prosedur Penelitian}

\section{Tahap Persiapan}

Tahap persiapan atau disebut juga tahap pemilihan telur (Sortasi) bertujuan untuk mengetahui secara pasti kondisi telur yang akan diasinkan, maka perlu dilakukan pemeriksaan sekaligus pemilihan (sortasi). Dimana harus dipastikan terlebih dahulu bahwa telur-telur yang akan digunakan tersebut merupakan telur yang belum pernah dierami sama sekali, sehingga kemungkinan adanya janin didalamnya dapat dihindari. Disamping itu, harus dihindari juga penggunaan telur yang telah mengalami keretakan atau pecah kulit, karena selama dalam perendaman putih telurnya akan menerobos keluar dan membuat larutan perendamannya berbau busuk. Agar kualitas telur asin bagus, pilih telur bebek yang segar dan berkualitas baik. Telur bebek yang diasinkan tidak boleh pecah, retak, atau lembek. Karenanya, 
pilih yang bercangkang keras dan tebal. Telur bebek yang dipakai sebaiknya masih baru, maksimum baru disimpan 2 hari. Akan lebih baik jika umur telur bebek tidak lebih dari 10 jam.

Pemeriksaan dilakukan dengan memasukan telur-telur tersebut ke dalam suatu wadah atau bak plastik yang telah diisi dengan air, kemudian mengamati posisi telur telur tersebut di dalam air. Telur yang melayang. harus segera dipisahkan, sedangkan telur yang tengelam atau yang setengah melayang dibiarkan terendam beberapa saat sehingga kotorannya mudah dibersihkan.

\section{Tahap Pelaksanaan}

1) Pencucian dan Pengamplasan Telur

Telur-telur yang baik, kemudian dicuci dengan sabun dan dibilas dengan air hingga benar-benar bersih, lalu ditiriskan. Berikut adalah langkah-langkah dalam pencucian:

a. Kelompokkan telur berdasarkan tingkat kebersihannya. kemudian bersihkan mulai dari kelompok kotor kemudian kelompok yang sangat kotor.

b. Telur yang kurang kotor dapat dibersihkan dengan kain/busa halus yang kering atau ampelas nomor 0 . Telur yang kotor dan sangat kotor ditempatkan diwadah terpisah dan dibersihkan dengan cara merendamnya dalam air detergen hangat selama 2 menit untuk melepaskan kotoran yang sudah mengering.

c. Teropong telur yang sudah kering. Perhatikan keutuhan kerabang, keadaan isi telur dan rongga udaranya. Pilihlah telur yang kerabangnya utuh/tidak retak dan isi telur terlihat bersih serta memiliki rongga udara lebih kecil.

d. Pengamplasan dilakukan untuk membuka pori-pori telur sehingga proses osmosis garam dapat dengan mudah masuk ke dalam telur dan diharapkan waktu yang digunakan dalam pengasinan bisa lebih cepat.

2) Pembuatan Adonan

a. Adonan Peram

Mencampur abu gosok dan batu bata hingga homogen, selanjutnya tambahkan garam sampai semua bahan menyatu, kemudian Asap cair ditambahkan ke dalam adonan dan Air dimasukkan sedikit demi sedikit hingga adonan dapat digenggam. 
b. Adonan Pasta

Proses pembuatannya sama dengan adonan peram, perbedaannya adalah menggunakan air lebih banyak hingga adonan membentuk pasta,

c. Adonan Larutan

Proses pembutan larutan garam jenuh ini berfungsi sebagai larutan perendam telur. Adapun proses pembuatannya diawali dengan memanaskan air hingga suhu tertentu (tidak perlu sampai mendidih) yang sekiranya cukup dapat membantu proses pelarutan garam dan saltpeter. Kemudian masukkan garam dan saltpeter, dan aduk hingga larut seleuruhnya. Selanjutnya angkat larutan garam jenuh tersebut dari perapian, dan diamkan beberapa saat hingga menjadi dingin kembali. Proses ini harus didahulukan karena membutuhkan waktu lama untuk mendinginkannya kembali.

3). Pemeraman, Perendaman dan Pasta

a) Pemeraman

Pemeraman dilakukan dengan membungkus telur menggunakan adonan yang telah tercampur dengan baik. Tiap sisi memiliki tingkat ketebalan yang sama yaitu $\pm 5 \mathrm{~cm}$, agar rasa asin dapat meresap ke dalam telur secara merata. Selanjutnya telur disimpan dalam wadah yang rata selama 7 hari.

b) Metode Pasta

Telur di benamkan masuk kedalam adonan pasta yang telah dibuat sebelumnya dengan memberi alas terlebih dahulu. Selanjutnya telur di atur dengan rata pada

c) Perendaman

Perendaman telur dilakukan selama 7 hari dalam larutan garam yang sudah didinginkan, agar menghasilkan telur asin yang rasa asinnya cukup enak untuk dinikmati. Sebelum telur-telur dimasukkan ke dalam wadah perendaman, terlebih dahulu letakkan wadah tersebut ditempat yang aman dan rata, untuk menghindari retak atau pecahnya telur pada saat proses perendaman wadah dan selanjutnya ditutupi kembali dengan adonan pasta yang maih tersisa hingga seluruh bagian tertutupi. 
4). Perebusan

Perebusan dilakukan dengan menggunakan api sedang selamam \pm 30 menit, dengan suhu $80^{\circ} \mathrm{C}$. Setelah itu telur didinginkan. Ssetelah dingin telur dikuliti kemudian dimasukkan ke dalam plastik klip.

5). Pengamatan

Pengamatan dilakukan dengan menggunakan peneli ssebanyak 20 orang. Sampel diberikan kepada peneliss beramaan dengan kuesioner untuk selanjutnya mereka dapat membubuhkan pendapatnya,

\section{Analisis Data}

Data yang diperoleh dianalisis secara sidik rgam berdasarkan Rancangan Acak Lengkap (RAL). Apabila perlakuan berpengaruh nyata, maka dilanjutkan dengan uji BNT (Beda Nyata Terkecil) (Steel dan Torrie, 1991).

$$
Y i j=\mu+\alpha i+\varepsilon i j
$$

Keterangan:

$$
\begin{aligned}
& \text { Yij = nilai pengamatan dari perlakuan ke-i ulangan ke-j } \\
& \mu=\text { nilai rata-rata sesungguhnya } \\
& \mathrm{ai}=\text { pengaruh perlakuan ke-i } \\
& \varepsilon \mathrm{ij}=\text { galat percobaan perlakuan ke-i ulangan ke-j } \\
& \mathrm{i}=\mathrm{P}_{1} \ldots . . \text { (perlakuan) } \\
& \mathrm{j}=1 \ldots \ldots \text { (ulangan }
\end{aligned}
$$

\section{HASIL DAN PEMBAHASAN}

Sifat telur ain yang diamati dalam penelitian ini adalah tingkat kemasiran telur dan Rasa. Pengujian dilakukan terhadap 20 orang panelis. Hasil penenlitian disajikan dalam tabel berikut:

\section{Aroma}

Hasil Penelitian penggunaan metode berbeda pada pembuatan telur asin terhadap aroma selama penelitian dapat dilihat pada Tabel 1.

Rataan hasil ketiga metode pembuatan telur asin terhadap aroma paling tinggi terdapat pada perlakuan perendaman, kemudian diikuti metode pengasinan dengan pasta dan terendah pada metode pengasinan dengan pemeraman. Analisis ragam 
dilakukan untuk mengetahui sejauhmana perbedaan ke tiga metode pengasinan terhadap aroma telur asin.

Tabel 1 : Hasil Rata-rata Uji Organoleptik Telur Asin berdasarkan Aroma

\begin{tabular}{|c|c|c|c|c|c|c|}
\hline \multirow{2}{*}{ Perlakuan } & \multicolumn{4}{|c|}{ Ulangan } & \multirow{2}{*}{ Total } & \multirow{2}{*}{ Rata-Rata } \\
\hline & 1 & 2 & 3 & 4 & & \\
\hline Metode Pemeraman & 6 & 5 & 4 & 4 & 19 & 4,75 \\
\hline Metode Pasta & 5 & 6 & 5 & 5 & 21 & 5,25 \\
\hline Metode Rendam & 6 & 7 & 6 & 6 & 25 & 6,25 \\
\hline Total & & & & & 65 & \\
\hline Rata Umum & & & & & & 5,42 \\
\hline
\end{tabular}

Hasil analisis ragam menunjukkan bahwa perbedaan metode pengasinan berpengaruh nyata $(\mathrm{P}<0,05)$ terhadap aroma telur asin. Untuk mengetahui sejauhmana pengaruh perbedaan metode pengainan terhadap aroma, dilanjutkan dengan Uji Jarak Berganda Duncan yang hasilnya tercantum pada Tabel 2.

Tabel 2. Hasil Uji Jarak Berganda Duncan terhadap Aroma Telur Asin

\begin{tabular}{lcc}
\hline Jenis Pengasinan & Rataan (gram) & Signifikansi 0,05 \\
\hline Metode pemeraman & 4,75 & $\mathrm{c}$ \\
Metode Pasta & 5,25 & $\mathrm{~b}$ \\
Metode Perendaman & 6,25 & $\mathrm{a}$ \\
\hline
\end{tabular}

Hasil Uji Jarak Berganda Duncan menunjukkan bahwa rasa asin pada telur yang dibuat dengan metode perendaman nyata lebih tinggi $(\mathrm{P}<0,05)$ dibandingkan dengan metode Pasta dan metode peram. Hal ini memberikan arti bahwa metode perendaman dapat mengurangi aroma/bau anyir pada telur dibandingkan dengan metode pasta dan peram. Garam yang terdapat pada telur selain berfungsi sebagai pemberi rasa juga berfungsi sebagai pembebas dari bau amis/busuk pada telur. Telur yang direndam dalam media garam akan menyebabkan laju difusi berlangsung cepat dikarenakan ukuran partikel garamnya kecil dan sebaliknya pada metode pasta dan peram laju difusinya berlangsung lambat dikarenakan ukuran partikelnya lebih besar sehingga kadar garam yang dijumpai dalam telur rendah yang kemudian menyebabkan bau amis pada telur lebih tinggi. Hal ini sesuai dengan pendapat Winarno dan Kowara (2002) bahwa ukuran kristal garam berpengaruh terhadap 
prosess difusi, dimana ukuran yang lebih besar $\left(6 \mathrm{~mm}^{3}\right)$ laju difusinya lambat, sedangkan ukuran kristal garam yang kecil (kurang dari $1 \mathrm{~m}^{3}$ ) laju difuinya cepat.

\section{Rasa}

Hasil Penelitian penggunaan metode berbeda pada pembuatan telur asin terhadap rasa selama penelitian dapat dilihat pada Tabel 3.

Tabel 3. Hasil Rata-rata Uji Organoleptik Telur Asin Berdasarkan Rasa

\begin{tabular}{ccccccc}
\hline \multirow{2}{*}{ Perlakuan } & \multicolumn{9}{c}{ Ulangan } & Total & \multirow{2}{*}{ Rata-Rata } \\
\cline { 2 - 5 } & $\mathbf{1}$ & $\mathbf{2}$ & $\mathbf{3}$ & $\mathbf{4}$ & & \\
\hline Metode Pemeraman & 6 & 6 & 6 & 6 & 25 & 6,25 \\
Metode Pasta & 6 & 7 & 6 & 6 & 24 & 6,00 \\
Metode Perendaman & 6 & 7 & 7 & 7 & 27 & 6,75 \\
\hline Total & 18 & 20 & 19 & 19 & 76 & \\
\hline Rata Umum & 6 & 6,67 & 6,33 & 6,33 & & 6,33 \\
\hline
\end{tabular}

Tabel 3 menunujukkan bahwa rataan tertinggi terdapat pada metode rendam, kemudian metode pasta dan terendah adalah pada metode peram. Analisis ragam dilakukan untuk mengetahui sejaumana pengaruh metode pengasinan yang berbeda pada pembuatan telur asin terhadap rasa.

Hasil analisis ragam menunjukan bahwa ke tiga metode pengasinan tidak berpengaruh nyata $(\mathrm{P}<0,05)$ pada rasa. Ini memberikan arti bahwa rasa asin yang diperoleh pada ketiga metode pengasinan memiliki kecenderungan sama. Hal ini disebabkan oleh karena jumlah garam dalam bahan yang digunakan adalah sama meskipun metode yang digunakan berbeda. Faktor lain adalah waktu pengasinan yang singkat sehingga rasa asin belum sampai kedalam isi telur. Hasil penelitian ini sejalan dengan pendapatt (Winarno dan Koswara, 2002) yang menyatakan bahwa rasa asin telur dipengaruhi oleh banyaknya garam yang masuk ke dalam telur setelah garam mengion menjadi $\mathrm{Na}+$ dan $\mathrm{Cl}$. Pengasinan merupakan proses penetrasi garam ke dalam bahan yang diasinkan dengan cara difusi. Laju difusi tergantung garam dan adonan. Semakin besar kandungan garam dalam adonan, maka semkin cepat laju difusi yang terjadi. 


\section{KESIMPULAN}

Metode Perendaman pada pembuatan telur asin selama 7 hari merupakan yang terbaik untuk mendapatkan aroma dibandingkan metode pembuatan telur asin dengan metode pasta dan pemeraman. Sebaiknya dalam pembuatan telur ain dapat digunakan metode perendaman guna untuk memperoleh aroma yang lebih baik, namun untuk mendapatkan rasa dapat memilih salah atu diantara tiga macam metode pembuatan telur asin.

\section{DAFTAR PUSTAKA}

Ali, U. 1992. Telur asin. Buletin Peternakan Indonesia. 151:09.

Astawan, M. 2003. Telur Asin. Aman dan Penuh Gizi. (Online), (http://www.Kompas.com/Kesehatan news, diakses 1 Juni 2010).

Budiman, A., Hintono, A, dan Kusrahayu. 2012. Pengaruh lama penyangraian telur asin setelah perebusan terhadap kadar $\mathrm{NaCl}$, tingkat keasinan dan tingkat kekenyalan. Animal Agriculture Journal, 1(2): 219-227.

Haryoto. 1996. Membuat Telur Asin. Kanisius, Yogyakarta.

Gaspersz, V. 1991. Metode Perancangan Percobaan untuk Ilmu-Ilmu Pertanian, IlmuIlmu Teknik, Biologi. CV. Armico, Bandung

Sarwono, B. 1994. Pengawetan dan Pemamfaatan Telur. Penebar Swadaya, Jakarta.

Soekarto, S.T. 1985. Penilaian Organoleptik untuk Industri Pangan dan Hasil Pertanian. Penerbit Bharatara Karya Aksara, Jakarta.

Winarno,F.G dan S. Koswara, 2002. Telur: Komposisi, Penanganan dan Pengolahannya. M-Brio Press, Bogor. 